\title{
PELAKSANAAN BIMBINGAN KARIER UNTUK MEMPERSIAPKAN SISWA MEMASUKI PERGURUAN TINGGI DI SMAN SE- JAKARTA UTARA
}

\author{
Resti Susanti ${ }^{1)}$ \\ ${ }^{1)}$ Jurusan Bimbingan dan Konseling, Fakultas Ilmu Pendidikan, Universitas Negeri Jakarta, Indonesia \\ E-mail:Pulaurempang@gmail.com
}

\begin{abstract}
Abstrak. Tujuan dari penelitian ini adalah untuk mengetahui pelaksanaan, peran Guru BK, dan hambatan yang di alami selama proses bimbingan karier untuk mempersiapkan siswa memasuki perguruan tinggi di SMAN Jakarta Utara. Jenis penelitian ini adalah penelitian survei menggunakan metode kualitatif. Narasumber penelitian ini adalah Koordinator BK SMAN di Jakarta Utara. Teknik pengumpulan data dalam penelitian ini menggunakan survei, wawancara dan dokumentasi. Keabsahan data penelitian diuji dengan menggunakan triangulasi sumber data dan triangulasi teknik pengumpul data. Teknik analisis data mengikuti konsep analisis data Miles dan Huberman yang terdiri dari reduksi data, penyajian data, dan penarikan kesimpulan. Dari penelitian ini dapat disimpulkan bahwa pelaksanaan bimbingan karier untuk mempersiapkan siswa memasuki perguruan tinggi di laksanakan sejak siswa duduk di kelas $\mathrm{X}$ semester pertama yaitu dengan memberikan informasi tentang jalur masuk ke perguruan tinggi terutama jalur masuk SNMPTN yaitu jalur masuk yang menggunakan nilai raport dari semester 1-5. Selanjutnya bimbingan karier dilaksanakan ketika siswa berada di kelas XII semester pertama pihak sekolah yang diprakarsai guru BK mengundang perguruan tinggi (universitas, institut, akademi, sekolah tinggi) untuk memberikan informasi kepada siswa, selain itu mengundang alumni yang sudah berhasil masuk di perguruan tinggi negeri untuk berbagi pengalamannya.Keterbatasan waktu yang dimiliki Guru BK menjadi salah satu hambatan sehingga kegiatan bimbingan karier untuk mempersiapkan siswa memasuki perguruan tinggi tidak bisa teroptimalisasikan.
\end{abstract}

Kata Kunci: Bimbingan Karier; Perguruan Tinggi

\section{Pendahuluan}

\section{A. LATAR BELAKANG}

Kurikulum SMA dirancang untuk mempersiapkan siswa melanjutkan pendidikan ke jenjang berikutnya. Setelah siswa melewati tahap kelulusan pendidikan di tingkat SMA, selayaknya ia melanjutkan pendidikan ke jenjang perguruan tinggi. Melanjutkan pendidikan keperguruan tinggi sangatlah penting bagi siswa SMA yang ingin menggali potensi dan kemampuan yang dimiliki. Namun pengambilan keputusan menentukan pilihan ke perguruan tinggi tidaklah mudah. Perjalanan dalam mengambil keputusan memilih keperguruan tinggi ternyata diperlukan pertimbangan yang matang. Memilih perguruan tinggi bagi siswa SMA sederajat, sama dengan memilih masa depan.

\section{B. PERMASALAHAN}

Perguruan tinggi merupakan lembaga pendidikan tertinggi yang menawarkan beragam disiplin ilmu yang mana hal ini membuat siswa terkadang harus menentukan sikap dalam mengambil keputusan untuk memilih program studi sesuai dengan minat dan bakat siswa. Banyaknya alternatif terkadang juga menjadi salah satu faktor yang mempengaruhi lama waktu yang dibutuhkan dalam membuat keputusan. Adapun ketidak tepatan siswa dalam mengambil keputusan studi lanjut salah satunya dapat disebabkan karena kurangnya informasi yang diperoleh siswa yang berkaitan tentang pendidikan lanjut ke perguruan tinggi. Hal ini dapat mengakibatkan siswa merasa tidak mempunyai gambaran tentang studi lanjutnya sehingga kesulitan dalam menentukan arah masa depan kariernya, siswa memilih studi lanjut bukan berdasarkan orientasi program studi, siswa tidak melakukan eksplorasi terhadap kekuatan dan kelemahan diri pada program studi yang akan diambil, serta tidak mandiri dalam mengambil suatu keputusan pemilihan 
studi lanjut, dengan kata lain selalu bergantung pada orang lain yang di anggap berarti baginya, dimana saran tersebut bersifat subyektif, sehingga akan menimbulkan kesulitan dalam belajar dan kecendrungan gagal dalam belajar, serta adanya asumsi yang keliru terhadap gengsi suatu program studi, hal-hal demikian akan menghambat proses untuk melakukan pilihan studi lanjut.

\section{TUJUAN}

Untuk menanggapi masalah yang dihadapi oleh peserta didik yang kurang informasi dalam pemilihan studi lanjut ke perguruan tinggi perlu bantuan para pembimbing seperti guru BK. Guru BK sangat berperan penting untuk membantu siswa serta dibutuhkan layanan bimbingan karir untuk mempersiapkan studi lanjut ke perguruan tinggi sehingga siswa mempunyai gambaran yang luas tentang perguruan tinggi.bimbingan karier adalah kegiatan bimbingan yang diberikan kepada siswa untuk memilih, menyiapkan diri, mencari, dan menyesuaikan diri terhadap karier yang sesuai dengan minat, bakat, dan kemampuannya sehingga dapat mengernbangkan dirinya secara optimal agar dapat menemukan karier dan melaksanakan karier yang efektif, memberi kepuasan dan kebahagiaan.

Konsep layanan BK dalam kurikulum 2013 tentang peminatan atau lebih tepatnya bantuan terhadap siswa dalam pemahaman mengenai bakat-minat, arah karier, serta pemilihan program studi atau jurusan yang diambil perlu pula didukung oleh kesiapan siswa dalam memahami lingkungan baru pada masa studi lanjutnya. Salah satu upaya mematangkan kesiapan studi lanjut siswa (dalam hal ini siswa SMA yang akan melanjutkan studi ke pendidikan tinggi) adalah dengan menyediakan informasi secara detail dan mendalam tentang wawasan dunia perguruan tinggi dan siswa memahami akan potensi yang dimiliki agar dapat memilih program studi dengan tepat. Bimbingan karier di SMA berperan penting dalam mengembangkan kemandirian siswa dalam memilih jenjang pendidikan lanjutan, serta dapat memberikan gambaran dan harapan yang akan dicapai oleh siswa di masa yang akan datang.

\section{KAJIAN PUSTAKA}

\section{Bimbingan Karier}

Frank Parson pada tahun 1908 ketika ia berhasil membentuk suatu lembaga yang bertujuan untuk membantu anak-anak muda memperoleh pekerjaan. Pada awalnya penggunaan istilah vocational guidance lebih merujuk pada usaha membantu individu memilih dan mempersiapkan suatu pekerjaan, termasuk didalamnya mempersiapkan kemampuan yang diperlukan untuk memasuki suatu pekerjaan.

Frank Parson (dalam [1]) menjelaskan, VocationalGuidance merupakan bantuan untuk mencari pekerjaan. Namun pengertian ini meluas, bukan hanya mencari pekerjaan saja. National Vocational Guidance Assosiation (dalam [2]) mengartikan sebagai pemberian penerangan, pengalaman dan nasehat dalam memilih, mempersiapkan, memasuki dan memperoleh kemajuan pekerjaan. Sedangkan Supriatna [3] mendefinisikan
Bimbingan karier adalah suatu proses bantuan, layanan, pendekatan terhadap individu agar dapat mengenal dan memahami dirinya, mengenal dunia kerja, merencanakan masa depan yang sesuai dengan bentuk kehidupan yang diharapkan, mampu menentukan dan mengambil keputusan secara tepat dan bertanggungjawab atas keputusan yang diambilnya itu sehingga mampu mewujudkan dirinya secara bermakna.

Berdasarkan beberapa definisi yang telah diuraikan di atas maka dapat diperoleh pengertian bahwa bimbingan karier adalah kegiatan bimbingan yang diberikan kepada siswa untuk memilih, menyiapkan diri, mencari, dan menyesuaikan diri terhadap karier yang sesuai dengan minat, bakat, dan kemampuannya sehingga dapat mengembangkan dirinya secara optimal agar dapat menemukan karier dan melaksanakan karier yang efektif, memberi kepuasan dan kebahagiaan.

\section{Tujuan Bimbingan Karier di SMA}

Dalam perspektif pendidikan nasional, pentingnya bimbingan karier sudah mulai dirasakan bersamaan dengan lahirnya gerakan bimbingan dan konseling di Indonesia pada pertengahan tahun 1950-an, berawal dari kebutuhan penjurusan siswa di SMA pada waktu itu. Pemberian bimbingan karier untuk siswa SMA ditujukan agar siswa dapat mengenal kemampuan dirinya, mengenal nilai-nilai yang ada pada dirinya, memahami lingkungan sekitar, dan mengenal dunia kerja atau situasi pendidikan tinggi [4].

Aktivitas bimbingan karier di SMA harus memiliki tiga penekanan yaitu mendorong perkembangan karier, menyediakan perlakuan, dan membantu penempatan (mengacu kepada perpindahan pelajar ketingkat pendidikan selanjutnya atau kekehidupan pekerjaan).Penekanan utama dalam aktivitas bimbingan karier bagi siswa haruslah didasarkan pada intensitas perencanaan, kesiapan berpartisipasi dalam kehidupan sebagai pribadi yang independent, dan keterarahan siswa kepada tujuan. Dalam hubungan dengan itu, the nasional conference on Guidance, Counseling, and placement in Career Development and Education Occupasional Decision-Makin Cysbers\&Pritchard (dalam[5]) merekomendasikan tujuan-tujuan untuk aktivitasaktivitas bimbingan karier di sekolah menengah sebagai berikut :

a. Siswa mengembangkan kesadaran akan perlunya implementasi yang lebih khusus dari tujuan-tujuan karier.

b. Siswa mengembangkan rencana-rencana yang lebih khusus guna mengimplementasikan tujuan-tujuan karier.

c. Siswa melaksanakan rencana-rencana untuk dapat memenuhi syarat-syarat memasuki pekerjaan dengan mengambil mata pelajaran di tingkat sekolah lanjutan, dengan latihan dalam jabatan, atau dengan mengejar latihan lebih lanjut di perguruan tinggi atau pendidikan pasca sekolah lanjutan yang mengantar pada kualifikasikualifikasi untuk suatu okupasi khusus

Penjelasan lain tentang tujuan bimbingan karier di SMA dikemukakan oleh Walgito [6], yaitu:

a. Mendidik para siswa untuk menjadi manusia pembangun dan sebagai warga negara Indonesia yang 
berpedoman pada Pancasila dan Undang-Undang Dasar 1945.

b. Memberi bekal kemampuan yang diperlukan bagi siswa yang akan melanjutkan pendidikan di perguruan tinggi, terutama di universitas dan institut.

c. Memberi bekal kemampuan yang diperlukan bagi siswa yang akan melanjutkan pendidikan di sekolah tinggi, akademi, politeknik, program diploma, dan atau program lainnya yang setingkat.

d. Memberi bekal kemampuan bagi siswa yang akan terjun ke dunia kerja setelah menyelesaikan pendidikannya.

\section{Perguruan Tinggi}

Perguruan tinggi merupakan jenjang pendidikan setelah pendidikan menengah yang mencakup program pendidikan diploma, sarjana, magister, spesialis, dan doktor yang diselenggarakan oleh pendidikan tinggi. Perguruan tinggi berkewajiban menyelenggarakan pendidikan, penelitian, dan pengabdian kepada masyarakat.Berdasarkan Undang-Undang SISDIKNAS Nomor 20 tahun 2003 tentang Sistem Pendidikan Nasional, pendidikan tinggi di Indonesia diklasifikasikan dalam 3 jenis, yaitu Pendidikan Akademik, Pendidikan Vokasi, dan Pendidikan Profesi/Spesialis [7].

Pendidikan Akademik adalah sistem pendidikan tinggi yang mengarah kepada penguasaan dan pengembangan disiplin ilmu pengetahuan, teknologi, dan seni tertentu. Pendidikan Akademik mencakup program pendidikan Sarjana (S1), Magister atau Master (S2) dan Doktor (S3). Lulusan Pendidikan Akademik akan mendapat gelar Sarjana, diikuti dengan bidang keahliannya. Misalnya, Sarjana Ekonomi (SE), Sarjana Hukum (SH), dan sebagainya.

Pendidikan Vokasi adalah sistem pendidikan tinggi yang mengarah kepada penguasaan keahlian terapan tertentu. Pendidikan Vokasi mencakup program pendidikan Diploma I (D1), Diploma II (D2), Diploma III (D3) dan Diploma IV (D4). Lulusan Pendidikan Vokasi akan mendapat gelar Vokasi, misalnya, Ahli Pratama (A.P.), Ahli Muda (A.Ma.), Ahli Madya (A.Md.), dan sebagainya.

Sedangkan Pendidikan Profesi/Spesialis adalah sistem pendidikan tinggi yang hanya dapat ditempuh setelah menyelesaikan program pendidikan Sarjana untuk dapat menguasai skill set spesifik yang dibutuhkan untuk menjajal profesi yang relevan. Lulusan Pendidikan Profesi/Spesialis akan mendapatkan Gelar Profesi yang sesuai dengan bidang pendidikan yang masing-masing ditempuh.

4. Jenis Perguruan Tinggi yang ada di Indonesia

a. Universitas

Universitas terdiri dari sejumlah fakultas yang menyelenggarakan Pendidikan Akademik dan/atau Pendidikan Vokasi dalam sejumlah ilmu pengetahuan, teknologi, atau seni. Jadi Universitas bisa menyelenggarakan dua jenis pendidikan tinggi yaitu Pendidikan Akademik dan Pendidikan Vokasi.

Universitas juga bisa menyelenggarakan pendidikan dalam berbagai rumpun ilmu tanpa batas. Misalnya, rumpun ilmu agama (syariah, ekonomi islam, ilmu penerangan agama Hindu, dan sebagainya), rumpun ilmu humaniora (filsafat, sejarah, bahasa, dan sebagainya), rumpun ilmu sosial (sosiologi, psikologi, ekonomi, dan sebagainya), rumpun ilmu alam (ilmu angkasa, ilmu kebumian, kimia, dan sebagainya), rumpun ilmu formal (komputer, matematika, statistika, dan sebagainya) dan rumpun ilmu terapan (pertanian, arsitektur dan perencanaan, bisnis, dan sebagainya). Jadi, bisa dibilang univeristas adalah perguruan tinggi yang menyediakan apa pun kebutuhan pendidikan tinggi.

\section{b. Institut}

Institut terdiri atas sejumlah fakultas yang menyelenggarakan Pendidikan Akademik dan/atau Pendidikan Vokasi dalam sejumlah ilmu pengetahuan, teknologi, dan seni. Sama seperti Universitas, Institut bisa menyelenggarakan dua jenis pendidikan tinggi juga, Pendidikan Akademik dan Pendidikan Vokasi.Misalnya, Institut Teknologi Bandung (ITB) hanya fokus kepada rumpun ilmu alam, sehingga fakultas-fakultas di ITB hanyalah yang terkait dengan ilmu alam, seperti ilmu angkasa, ilmu kebumian, ilmu biologi, ilmu kimia, ilmu fisika, dan sebagainya.Perbedaan institute dengan universitas adalah fakultas-fakultas dalam sebuah institut berasal dari satu jenis keilmuan saja. Sedangakan universitasterdiri dari fakultas-fakultas yang berasal dari berbagai jenis keilmuan. c. Sekolah Tinggi

Sekolah Tinggi adalah perguruan tinggi yang melaksanakan Pendidikan Akademik dan/atau Pendidikan Vokasi dalam sejumlah ilmu pengetahuan, teknologi, dan seni. Sama seperti Universitas dan Institut, Sekolah Tinggi bisa menyelenggarakan Pendidikan Akademik dan Pendidikan Vokasi.Namun, berbeda dengan Universitas dan Institut, Sekolah Tinggi cuma terdiri dari satu fakultas yang terbagi ke dalam berbagai program studi. Misalnya, Sekolah Tinggi Ilmu Komunikasi hanya menyediakan program studiprogram studi dari Fakultas Komunikasi, seperti Hubungan Masyarakat, Penyiaran, Periklanan, dan sebagainya.Contoh Sekolah Tinggi di Indonesia adalah London School of Public Relationatau Sekolah Tinggi Ilmu Komputer Indonesia.

\section{d. Politeknik}

Politeknik adalah sekolah tinggi yang hanya menyelenggarakan Pendidikan Vokasi. Jadi Politeknik nggak menyelenggarakan Pendidikan Akademik. Sesuai dengan jenis pendidikan tinggi yang ditawarkan, tujuan politeknik sendiri tentunya untuk mempersiapkan siswanya untuk menjadi anggota masyarakat yang punya kemampuan profesional agar mampu menerapkan, mengembangkan, dan menyebarluaskan ilmu pengetahuan dan teknologi agar taraf hidup masyarakat dan kesejahteraan umat manusia meningkat.

\section{e. Akademi}

Sama seperti Politeknik, Akademi adalah sekolah tinggi yang hanya menyelenggarakan Pendidikan Vokasi dalam satu atau sebagian cabang ilmu pengetahuan, teknologi atau seni tertentu. Beda antara Politeknik dan Akademi adalah, Politeknik bisa menyelenggarakan Pendidikan Vokasi dari beberapa rumpun ilmu, sedangkan Akademi hanya bisa menyelenggarakan Pendidikan Vokasi dari satu cabang ilmu saja. Misalnya, di Politeknik Negeri Jakarta (PNJ) tersedia program studi dalam rumpun ilmu 
rekayasa (teknik elektro, teknik mesin, teknik kimia, dan sebagainya) dan rumpun ilmu tata niaga (akuntansi, bisnis, manajemen, dan sebagainya). Sementara Akademi Sekretaris dan Manajemen Don Bosco hanya berisi program studi seputar Kesekretariatan dan Manajemen.

Dalam hal pengelolaan, perguruan tinggi juga terbagi lagi menjadi 3, yaitu:

1) Perguruan Tinggi Negeri (PTN), yaitu perguruan tinggi yang dikelola oleh pemerintahan, baik langsung berada di bawah Departemen Pendidikan Nasional maupun di bawah departemen lain milik pemerintah.

2) Perguruan Tinggi Swasta (PTS), yaitu perguruan tinggi yang dimilliki dan dikelola oleh perorangan atau kelompok/yayasan tertentu.

3) Perguruan Tinggi Kedinasan (PTK), yaitu perguruan tinggi di bawah departemen selain Departemen Pendidikan Nasional, atau merupakan lembaga pendidikan tinggi negeri yang memiliki ikatan dengan lembaga pemerintahan sebagai penyelenggara pendidikan.

5. Jalur Masuk Perguruan Tinggi

a. SNMPTN

SNMPTN adalah kepanjangan dari Seleksi Nasional Masuk Perguruan Tinggi Negeri. SNMPTN merupakan pola seleksi nasional berdasarkan hasil penelusuran prestasi akademik dengan menggunakan rapor semester 1 (satu) sampai dengan semester 5 (lima) bagi SMA/SMK/MA atau sederajat dengan masa belajar 3 (tiga) tahun atau semester 1 (satu) sampai dengan semester 7 (tujuh) bagi SMK dengan masa belajar 4 (empat) tahun, serta portofolio akademik. Sekolah yang siswanya berhak mengikuti SNMPTN adalah SMA/SMK/MA atau sederajat (termasuk SRI di luar negeri) yang mempunyai NPSN (Nomor Pokok Sekolah Nasional) dan telah mengisi PDSS (Pangkalan Data Siswa Sekolah) dengan lengkap dan benar. Informasi lengkap tentang SNMPTN bisa dapatkan di http://snmptn.ac.id/.

\section{b. $P M D K-P N$}

Jalur PMDK-PN (Penelusuran Minat dan Kemampuan Politeknik Negeri) merupakan seleksi Jalur Undangan yang diperuntukkan bagi calon peserta/siswa sekolah yang akan melanjutkan pendidikan di Perguruan Tinggi Bidang Vokasi atau Politeknik Negeri di seluruh wilayah Indonesia. Pola seleksi ini tertuang dalam suatu sistem yang terpadu dan diselenggarakan secara serentak melalui seleksi prestasi akademik siswa selama mengikuti pendidikan di Sekolah Lanjutan Tingkat Atas. Informasi lengkap serta tata cara pendaftaran Jalur PMDK-PN dapat diakses pihak sekoiah melalui situs pmdk.politeknik.or.id.

\section{c. SBMPTN}

SBMPTN adalah kepanjangan dari Seleksi Bersama Masuk Perguruan Tinggi Negeri, yaitu seleksi berdasarkan hasil ujian tertulis dalam bentuk cetak (paper based testing) atau menggunakan komputer (computer based testing), atau kombinasi hasil ujian tertulis dan ujian keterampilan calon Mahasiswa, dilakukan secara bersama di bawah koordinasi panitia pusat. Informasi SBMPTN meliputi: ketentuan dan persyaratan umum, tata cara pembayaran biaya seleksi, tata cara pendaftaran, jadwal pelaksanaan, dan jumlah pilihan
PTN serta program studi. Secara rinci, informasi lengkap mengenai SBMPTN dapat dilihat di laman sbmptn.ac.id.

d. Ujian Masuk Perguruan Tinggi Kedinasan

Perguruan Tinggi Kedinasan (PTK) merupakan lembaga pendidikan tinggi negeri yang ada ikatan dengan lembaga pemerintah / kementrian sebagai penyelenggara pendidikan. PTK menawarkan kuliah yang biaya terjangkau dan beberapa gratis dan mendapatkan uang saku setiap bulan, beberapa diantaranya semi militer. PTK berbeda dengan PTN, di PTK mahasiswa akan kuliah dan setelah lulus dapat langsung bekerja.

Tantangan kuliah di PTK adalah mahasiswa dituntut untuk belajar sebaik mungkin dan mampu lulus ujian setiap semester dengan nilai yang baik. Contoh dari institusi kedinasan antara lain; Politeknik Keuangan Negara STAN, Sekolah Tinggi Ilmu Statistika, Institut Pendidikan Dalam Negeri, Akademi Imigrasi, Sekolah Tinggi Sandi Negara, Sekolah Tinggi Meterologi Klimatologi dan Geofisika, Sekolah Tinggi Transportasi Darat. Informasi lengkap pendaftaran jalur ini bisa diakses di alamat PTK masing masing.

e. UMPN

UMPN (Ujian Masuk Politeknik Negeri) merupakan seleksi penerimaan mahasiswa baru Politeknik Negeri Jember melalui ujian tulis bersama-sama dengan 43 Politeknik Negeri Se-Indonesia. Jalur masuk ini merupakan salah satu jalur masuk yang cukup diminati, untuk yang lulus jalur ini akan kuliah disalah satu Politeknik Negeri dengan ketentuan reguler, biasanya setiap Politeknik Negeri memiliki dua kelompok masuk, yaitu kampus Pagi dan Kampus siang.

Perbedaannya adalah jalur masuk untuk lulusan UMPN akan mendapatkan kesempatan kampus pagi, meski setiap Politeknik Negeri memiliki jalur seleksi ini tetapi sistem penyelenggaraan kembali kepada kampus masing-masing tidak seperti jalur PMDK PN yang diatur secara keseluruhan oleh panitia umum, sedangkn untuk UMPN dilaksanakan melalui Politeknik masing-masing. Untuk jalur UMPN ini tidak ada panitia pusat, jadi kalian harus mencari info dari web masing-masing politeknik.

\section{f. Mandiri PTN/ PTS}

Jalur Seleksi Mandiri adalah jalur penerimaan mahasiswa baru yang diselenggarakan secara khusus oleh panitia dari Perguruan Tinggi Penyelenggara baik itu Perguruan Tinggi Negeri (PTN) atau Perguruan Tinggi Swasta (PTS). Jalur seleksi mandiri di setiap Perguruan Tinggi memiliki nama dan sistem penerimaan yang berbedabeda. Waktu penyelenggaraan seleksi mandiri ini juga beragam, ada Perguruan Tinggi yang menyelenggarakan sebelum SBMPTN, dan ada yang menyelenggarakan setelahnya. Jika kalian ingin mengikuti jalur mandiri ini, maka harus rajin mengakses informasi terkait dari alamat web Perguruan Tinggi yang dituju. 


\section{METODE}

\section{A. PENDEKATAN DAN JENIS PENELITIAN}

Metode merupakan salah satu komponen yang sangat penting dalam suatu penelitian. Berdasarkan tujuan umum penelitian maka metode yang tepat dalam penelitian penelitian ini adalah metode deskriptif, karena dilakukan pada saat sekarang dengan sebagaimana adanya. Sebagaimana telah dikemukakan oleh Subana dan Sudrajat [8] mengatakan: "Penelitian deskriptif menuturkan dan menafsirkan data yang terjadi pada saat penelitian ini berlangsung dan berlangsung dan menyajikan apa adanya. Metode deskriftif adalah suatu bentuk penguraian dan penginterpretasian yang memiliki kaitan dengan kondisikondisi yang ada, proses yang sedang berlangsung atau kecendrungan-kecendrungan yang sedang berkembang.

Setelah metode ditentukan, maka bentuk penelitian harus sesuai dengan metode yang digunakan. Karena metode penelitian yang digunakan dalam penelitian ini adalah metode deskriptif, maka bentuk penelitian pun sesuai dengan metode tersebut. Bentuk penelitian yang tepat dalam penelitian ini adalah "bentuk penelitian survey". Bentuk penelitian ini dilakukan dengan cara peneliti mengadakan survey langsung ke lokasi yang menjadi tempat penelitian.

Sejalan dengan hal tersebut Sugiyono [9] mengatakan: "survei pada umumnya merupakan data dari sejumlah unit atau individu dalam waktu yang bersamaan". Dengan demikian penelitian ini dilaksanakan dengan mengadakan survey langsung ke SMA N yang ada di wilayah Jakarta Utara yaitu SMAN 13, SMAN 18, SMAN 15, SMAN 40, SMAN 45, dan SMAN 72, menghimpun data-data yang diperlukan, kemudian menganalisis dan mendeskrifsikan data-data tersebut hingga diperoleh jawaban pertanyaanpertanyaan.

\section{B. SUMBER DATA}

Sumber data didapatkan dari penelitian yang dilakukan. Menurut Arikunto [10] Sumber data adalah tempat, orang atau benda dimana peneliti dapat mengamati, bertanya atau membaca tentang hal-hal yang berkenaan dengan variabel yang diteliti. Dalam penelitian ini menggunakan purposive sampling, menurut Arikunto [10] "purposive sampling yaitu teknik sampling yang digunakan oleh peneliti jika peneliti mempunyai pertimbanganpertimbangan tertentu di dalam pengambilannya sampelnya".

TABEL I

SUMBER DATA

\begin{tabular}{lll}
\hline No & Jabatan & Asal Sekolah \\
\hline 1 & Koordinator BK & SMAN 13 \\
2 & Koordinator BK & SMAN 18 \\
3 & Koordinator BK & SMAN 15 \\
4 & Koordinator BK & SMAN 40 \\
5 & Koordinator BK & SMAN 45 \\
6 & Koordinator BK & SMAN 72 \\
\hline
\end{tabular}

\section{TEKNIK ANALISIS DATA}

Dalam penelitian ini peneliti menggunakan teknik analisis mengikuti konsep dari Miles and Huberman. Miles and Huberman (dalam [9]) mengemukakan bahwa aktivitas analisis data kualitatif dilakukan secara interaktif dan berlangsung secara terus menerus pada setiap tahapan penelitian hingga datanya jenuh.

Teknik analisis data yang digunakan adalah model Miles dan Huberman:

1. Reduksi data (data reduction), berarti merangkum, memilih hal-hal yang pokok, memfokuskan pada hal-hal yang penting, dicari tema dan polanya. Dengan demikan data yang telah direduksi akan memberikan gambarangambaran yang lebih jelas, dan mempermudah peneliti untuk melakukan pengumpulan data selanjutnya, dan mencarinya bila diperlukan.

2. Penyajian data (data display), artinya penyajian data bisa dilakukan dalam bentuk uraian singkat, bagan, hubungan antar kategori, flowchart dan sejenisnya. Yang paling sering digunakan dalam penelitian kualitatif adalah teks yang bersifat naratif. Dalam melakukan display data, selain dengan teks yang naratif, juga dapat berupa, grafik, matrik, network (jejaring kerja) dan chart.

3. Penarikan kesimpulan dan verifikasi (conclusion drawing), artinya kesimpulan yang dikemukakan masih bersifat sementara, dan akan berubah bila tidak ditemukan masih bersifat sementara, dan akan berubah bila ditemukan bukti-bukti yang kuat yang mendukung pada tahap pengumpulan data berikutnya. Tetapi apabila kesimpulan dikemukan pada tahap awal, didukung oleh bukti-bukti yang valid dan konsisten saat peneliti kembali ke lapangan mengumpulkan data, maka kesimpulan yang dikemukan merupakan kesimpulan yang kredibel.

\section{TEKNIK PENGUMPULAN DATA}

Pengumpulan data menggunakan metode survey, wawancara dan dokumentasi. Dalam penelitian ini peneliti menggunakan triangulasi teknik pengumpulan data dan sumber data sebagai uji keabsahan data.

\section{HASIL DAN PEMBAHASAN}

A. HASIL

1. Hasil Wawancara

a. Hasil Wawancara dengan Guru BK di SMAN 13

Berdasarkan hasil wawancara dengan koordinator BK di SMAN 13 Jakarta Utara, peneliti mendapatkan data tentang layanan bimbingan karier untuk mempersiapkan siswa memasuki perguruan tinggi. Pelaksanaan layanan bimbingan karier dilakukan sejak semester satu tepatnya pada saat siswa duduk di kelas $\mathrm{X}$, yaitu dengan mengenalkan jalur untuk masuk ke perguruan tinggi dengan menggunakan nilai raport dari semester $1-5$, tujuannya agar siswa mempersiapkan diri dengan belajar lebih giat.

Di semester awal kelas XII, siswa di motivasi untuk mencari informasi tentang perguruan tinggi, salah satunya tentang program studi, sehingga siswa 
memiliki wawasan tentang perguruan tinggi.Untuk mengetahui minat siswa mengenai studi lanjut ke perguruan tinggi maka Guru BK meminta siswa untuk menuliskan 2 program studi yang siswa minati. Sebelumnya Guru BK sudah membuat kriteria berdasarkan nilai akademik, tes bakat minat (jika siswa memiliki), dan kemampuan orang tua dengan program studi pilihan siswa.

Siswa yang memilih program studi sesuai dengan kriteria yang dibuat Guru BK maka akan dimotivasi untuk mencari informasi sebanyak-banyaknya dari berbagai sumber termasuk guru BK dan sebaliknya siswa yang memilih program studi tidak sesuai dengan kriteria yang dibuat Guru BK, siswa tersebut akan dipanggil untuk dilakukan konseling agar siswa memilih program studi di perguruan tinggi sesuai dengan kriteria yang dibuat Guru BK. Hambatan yang dialami Guru BK adalah keterbatasan waktu,sehingga pelaksanaan bimbingan karier untuk mempersiapkan siswa memasuki perguruan tinggi belum optimal.

b. Hasil Wawancara di SMAN 15

Berdasarkan hasil wawancara yang di laksanakan dengan koordinator BK di SMAN 15 Jakarta, pelaksanaan bimbingan karier di SMAN 15 untuk mempersiapkan siswa memasuki perguruan tinggi, diberikan kepada siswa kelas $\mathrm{X}$, yaitu dengan mengenalkan jenis-jenis perguruan tinggi yang ada di Indonesia dan jalur-jalur masuk ke perguruan tinggi salah satunya jalur masuk yang mengunakan nilai raport 1-5 yaitu jalur masuk SNMPTN. Untuk siswa kelas XI antusias untuk bertanya atau mencari informasi tentang studi lanjut sangat minim tetapi bagi yang berminat guru BK mempersilahkan untuk datang berkonsultasi. Siswa kelas XII, antusias untuk mencari informasi tentang studi lanjut sangat tinggi, ini dibuktikan banyak sekali siswa yang mendatangi guru BK untuk berkonsultasi.

Langkah selanjutnya untuk lebih memantapkan wawasan siswa tentang dunia perguruan tinggi maka pihak sekolah yang di prakarsai guru BK mengundang perguruan tinggi (universitas, institute, akademi, sekolah tinggi).Tujuannya adalah untuk memberikan informasi kepada siswa.Selain itu juga mengundang alumni yang sudah berhasil masuk di perguruan tinggi negeri untuk berbagi pengalamannya.

Hambatan dalam pelaksanaan bimbingan karier bagi guru BK di SMAN 15 adalah keterbatasan waktu. Pelaksanaan bimbingan karier studi lanjut ke perguruan tinggi selama ini masih dilaksanakan secara insidental. Akibatnya Pelaksanaan bimbingan karier untuk studi lanjut ke perguruan tinggi tidak bisa dilaksanakan dengan optimal, yaitu belum dapat dilakukan secara personal dengan memperhatikan pilihan siswa dan di sesuaikan dengan kemampuan yang dimiliki oleh siswa secara keseluruhan. c. Hasil Wawancara di SMAN 18

Berdasarkan hasil wawancara dengan koordinator BK di SMAN 18 Jakarta. Pelaksanaan bimbingan karier untuk mempersiapkan siswa memasuki perguruan tinggi di lakukan kepada siswa kelas X. Diawali dengan memberikan informasi cara masuk perguruan tinggi melalui jalur SNMPTN yaitu menggunakan nilai raport dari semester 1 sampai 5.Tujuannya agar siswa dapat mempersiapkan diri untuk belajar sungguh-sungguh sehingga memiliki nilai raport yang memenuhi syarat untuk ikut seleksi masuk perguruan tinggi melalui jalur SNMPTN.

Bagi siswa yang tidak lolos masuk jalur SNMPTN di perkenalkan jalur lain salah satunya SBPTN dan diberikan berbagai informasi persyaratannnya. Bagi siswa yang ingin berkonsultasi tentang studi lanjut keperguruan tinggi Guru BK mempersilahkan datang ke ruang BK, biasanya Guru BK menanyakan terlebih dahulu minat dari siswa ingin memilih program studi apa, lalu guru BK bersama-sama siswa menganalisisnya disesuaikan dengan nilai akademik, tes IQ dari psikolog (apabila siswa memiliki), kalau tidak ada biasanya hanya berdasarkan minat, dan prestasi belajar.

Tidak jauh berbeda dengan sekolah sebelumnya hambatan dalam pelaksanaan bimbingan karier adalah masalah waktu. Guru BK merasa tidak optimal dalam memberikan bimbingan karier studi lanjut ke perguruan tinggi.Walaupun demikian guru BK selalu siap dan menerima dengan tangan terbuka apabila ada siswa yang ingin berkonsultasi.

d. Hasil Wawancara di SMAN 40

Berdasarkan hasil wawancara dengan koordinator BK di SMAN 40 Jakarta, pelaksanaan bimbingan karier untuk mempersiapkan siswa memasuki perguruan tinggi di lakukan melalui konsultasi karier kepada guru BK, mengadakan pameran pendidikan yang mengundang perguruan tinggi, mengundang alumni yang sudah ada di fakultas masing-masing serta mengadakan seminar dengan narasumber alumni yang sudah sukses dalam kariernya, dan memberikan berbagai informasi tentang perguruan tinggi, karena keterbatasan waktu yang dimiliki guru BK maka siswa dimotivasi untuk mengeksplor informasi tentang perguruan tinggi dari berbagai sumber.

e. Hasil Wawancara di SMAN 45

Berdasarkan hasil wawancara dengan koordinator BK di SMAN 45 Jakarta, pelaksanaan bimbingan karier untuk studi lanjut ke perguruan tinggi dilakukan dengan cara memotivasi siswa untuk belajar lebih giat dimulai dari kelas $\mathrm{X}$, guru $\mathrm{BK}$ memberikan informasi tentang jalur masuk perguruan tinggi yang menggunakan nilai raport dari semester 1 sampai semester 5. Disamping itu guru BK mulai memperkenalkan jenis perguruan tinggi dan program studi yang ada di perguruan tinggi. Karena keterbatasan waktu guru BK untuk masuk kelas, pelaksanaan bimbingan karier belum optimal karena 
guru BK lebih memproitaskan pelayanan yang lebih penting, seperti menyelesaikan masalah-masalah yang dialami oleh siswa yang dapat mengganggu kelangsungan belajar siswa.

Agar siswa memiliki wawasan tentang sekolah lanjut ke perguruan tinggi, guru BK mempersilahkan siswa yang membutuhkan layanan datang ke ruangan BK untuk berkonsultasi. Selain itu guru BK memotivasi siswa untuk mencari informasi tentang perguruan tinggi sebanyak-banyaknya terutama tentang perguruan tinggi dan program studi yang diminati.

f. Hasil Wawancara di SMAN 72

Berdasarkan hasil wawancara dengan koordinator BK di SMAN 72 Jakarta, pelaksanaan bimbingan karier untuk mempersiapkan siswa memasuki perguruan tinggi dilakukan ketika siswa duduk di kelas X yaitu dengan mengenalkan jalur masuk SNMPTN yaitu jalur masuk perguruan tinggi dengan menggunakan nilai raport, dari semester 1-5 tujuannya agar siswa dapat mempersiapkan diri sejak dini. Selanjutnya untuk siswa kelas XII, diberikan layanan informasi dengan memperkenalkan jenis-jenis program studi di perguruan tinggi.

Tahapan selanjunya Guru BK mengumpulkan data nilai rapot, nilai $\mathrm{UN}$, hasil tes RAISEK yang dilakukan secara manual lalu hasilnya dicocokan dengan program studi pilihan siswa. Tahap ini prosesnya membutuhkan waktu dan tenaga sehingga hasilnya tidak bisa diinformasikan pada siswa dengan cepat.Hal ini karena keterbatan waktu sehingga hanya diberikan pada siswa yang membutuhkan saja.Siswa yang menghubungi Guru BK dapat melaksanakan konsultasi di ruangan $\mathrm{BK}$, dan membahas hasil tes RAISEK lalu dicocokan dengan nilai raport,dan nilai UN. Guru BK sadar, pelaksanaan bimbingan karier untuk studi lanjut ke perguruan tinggi belum dilaksanakan dengan optimal karena belum dapat melayani kepada seluruh siswa.

\section{Hasil Data Dokumentasi}

Data dokumentasi yang berupa arsip merupakan catatan konselor, arsip, brosur perguruan tinggi, lembar RAISEC dan format-format tertentu dari bimbingan konseling sekolah yang digunakan selama proses pelaksanaan bimbingan karier untuk mempersiapkan siswa memasuki perguruan tinggi.

\section{B. PEMBAHASAN}

Melanjutkan studi ke perguruan tinggi (memilih program studi), bagi siswaadalah hal yang penting karena sama dengan memilih karier di masa depan. Hal ini dijelaskan juga oleh Gunawan [11] bahwa: "Pilihan untuk memasuki perguruan tinggi atau dengan kata lain melanjutkan studi atau pendidikan ke perguruan tinggi adalah salah satu persoalan yang sangat penting yang dihadapi oleh orangtua dan siswa Sekolah Menengah Atas"

Lebih lanjut Supriatna [3] menjelaskan masalah karier yang dirasakan siswa SMA diantaranya adalah siswa belum memiliki pilihan perguruan tinggi atau lanjutan pendidikan tertentu setelah lulus SMA dan siswa kurang memahami cara memilih program studi yang cocok dengan kemampuan dan minat. Oleh sebab itu, sebelum membuat pilihan studi lanjut, siswa perlu membuat perencanaan yang matang atas beberapa informasi yang telah diperoleh, sehingga pada akhirnya siswa mampu membuat keputusan yang tepat atas pilihan studi lanjut sesuai dengan keadaan diri dan lingkungannya, serta keputusan yang dibuat tersebut tidak menimbulkan penyesalan dikemudian hari.

Pelaksanaan bimbingan karier untuk studi lanjut keperguruan tinggi dilaksanakan untuk memberikan bantuan kepada siswa dalam pemahaman mengenai kemampuan, bakat-minat dan wawasan tentang perguruan tinggi. Pemilihan program studi yang diambil perlu pula didukung oleh kesiapan siswa dalam memahami lingkungan baru pada masa studi lanjutnya.Winkel [12], juga menjelaskan bahwa salah satu upaya mematangkan kesiapan studi lanjut siswa (dalam hal ini siswa SMA yang akan melanjutkan studi ke pendidikan tinggi) adalah dengan menyediakan informasi secara detail tentang diri sendiri dan wawasan dunia perguruan tinggi.

Informasi yang akurat tentang wawasan dunia perguruan tinggi dan diri sendiri merupakan hal yang penting untuk mempengaruhi persepsi siswa terhadap keputusan kariernya agar siswa dapat menyesuaikan pilihan karier dengan potensi dirinya. Lebih jauh Frank Parson, dalam bukunya Choosing a Vocation Winkel \& Hastuti [13], menunjukkan tiga langkah yang harus diikuti dalam memilih karier yang sesuai, yaitu: pemahaman diri yang jelas mengenai kemampuan otak, bakat, minat, berbagai kelebihan dan kelemahan, serta ciri-ciri yang lain. Pengetahuan tentang keseluruhan persyaratan yang harus dipenuhi supaya dapat mencapai sukses dalam berbagai bidang pekerjaan, serta mengintegrasikan informasi tentang diri dan dunia kerja.

Data yang didapatkan dari hasil wawancara, dengan beberapa koordinator guru BK ada banyak kegiatan yang di lakukan dalam membantu siswa untuk mempersiapkan siswa memasuki perguruan tinggi. Data yang didapat dari hasil wawancara, hampir memiliki kesamaan informasi yaitu pelaksanaan bimbingan karier untuk mempersiapkan siswa memasuki perguruan tinggi, diberikan mulai dari siswa berada di kelas $\mathrm{X}$ yaitu dengan memberikan informasi tentang jalur-jalur masuk perguruan tinggi salah satunya adalah jalur masuk perguruan tinggi menggunakan nilai raport dari semester 1-5 yaitu jalur masuk SNMPTN yang tujuannya, agar siswa dapat mempersiapkan diri dengan belajar lebih giat sehingga memiliki nilai raport yang sesuai dengan persyaratan jalur masuk menggunakan nilai raport dari semester 1 dan 5 yaitu jalur SNMPTN. Selain itu pemberian informasi tentang perguruan tinggi satu diantaranya informasi tentang program studi yang ada diperguruan tinggi yang dapat dipilih ketika siswa akan melanjutkan studi ke perguruan tinggi.

Untuk siswa kelas XII. Kegiatan bimbingan karier untuk mempersiapkan siswa memasuki perguruan tinggi frekuensinya ditingkatkan, agar siswa memiliki wawasan dan mampu menentukan program studi dan perguruan tinggi 
dengan tepat sesuai dengan kemampuan yang dimiliki, yaitu dengan mengadakan pameran pendidikan yang mengundang perguruan tinggi dan alumni yang sudah ada di fakultas masing-masing serta ada seminar dengan narasumber alumni yang sudah sukses dalam karier. Selain itu untuk mengetahui program studi yang diminati siswa Guru BK meminta siswa untuk menuliskan dua program studi yang diminati, dikumpulkan dan diserahkan pada Guru BK,untuk disesuaikan dengan kemampuan siswa lalu dianalisis kesuaian dengan kriteria yang telah dibuat Guru BK.

Hambatan pelaksanaan bimbingan karier studi lanjut ke perguruan tinggi adalah keterbatasan waktu yang dimiliki guru BK, sehingga bimbingan karier untuk mempersiapkan siswa memasuki keperguruan tinggi tidak bisa diberikan kepada seluruh siswa secara personal. Guru BK sadar bahwa siswa yang akan melanjutkan studi lanjut ke perguruan tinggi harus memiliki informasi tentang perguruan tinggi, dan tidak kalah penting siswa juga harus memiliki pengetahuan tentang pemahaman diri yaitu potensi yang dimiliki dan dicocokan dengan pilihan program studi yang sesuai.

\section{KESIMPULAN}

Beberapa Sekolah Menengah Atas Negeri yang ada di wilayah Jakarta Utara telah melaksanakan bimbingan karier untuk mempersiapkan siswa memasuki perguruan tinggi. Berbagai cara dilakukan yaitu dengan memberikan informasi tentang perguruan tinggi seperti jenis-jenis jalur masuk perguruan tinggi dan jenis program studi yang ada di perguruan tinggi.

Pada awal semester yaitu ketika siswa berada di kelas $\mathrm{X}$, bimbingan karier untuk studi lanjut ke perguruan tinggi sudah dilaksanakan. Siswa diberikan informasi jalur masuk perguruan tinggi menggunakan nilai raport dari semester 15 , yang tujuan agar siswa mempersiapkan diri sehingga memiliki nilai raport yang sesuai dengan persyaratan. Siswa kelas XI belum tertarik untuk mendapatkan informasi tentang perguruan tinggi, ini dibuktikan banyak siswa yang tidak antusias ketika bimbingan karier dilaksanakan, mereka beralasan, waktunya masih lama untuk mencari informasi tersebut.

Pelaksanaan bimbingan karier sangat penting bagi siswa kelas XII, mereka sangat bersemangat dan antusias untuk mengikuti bimbingan karier, bahkan mereka bolakbalik keruangan BK untuk berkonsultasi, untuk membantu siswa agar memiliki wawasan yang dibutuhkan. Pihak sekolah yang diprakarsai oleh guru BK mengundang perguruan tinggi untuk memberikan informasi kepada siswa, selain itu alumni yang telah berada di perguruan tinggi juga dilibatkan untuk memberikan informasi tentang pengalaman mereka dalam menempuh studi lanjut di perguruan tinggi.

\section{UCAPAN TERIMA KASIH}

Kami ingin mengucapkan terima kasih kepada Guru BK di SMA Negeri 13, SMA Negeri 15, SMA Negeri 18, SMA Negeri 40, SMA Negeri 45, SMA Negeri 72, yang telah menerima dengan hangat dan terbuka untuk melakukan wawancara tentangpelaksanaan bimbingan karier untuk mempersiapkan siswa memasuki perguruan tinggi, sehingga peneliti mendapatkan informasi yang dibutuhkan.

\section{DAFTAR PUSTAKA}

[1] Gladding, S. T. (2012). Konseling: Profesi yang Menyeluruh. Indeks: Jakarta

[2] Prayitno. \& Amti, E. (2004). Layanan Bimbingan dan Konseling kelompok. Padang: Jurusan Bimbingan dan Konseling Fakultas Ilmu Pendidikan Universitas Negeri Padang.

[3] Supriatna, M. (2009). Layanan Bimbingan Karir di Sekolah Menengah. Bandung: Universitas Pendidikan Indonesia \& PT. Remaja Rosdakarya.

[4] Depdiknas. (2004). Kerangka Dasar Kurikulum 2004. Jakarta.

[5] Rauf, M. Y. (2006). Program Bimbingan Karir Untuk Mencapai Kematangan Karir SMA (Dikembangkan Berdasarkan Studi Deskriptif Tentang Kematangan Karir Siswa dan Layanan Bimbingan Karir di Beberapa SMA Negeri Kota Pekanbaru Provinsi Riau). Bandung: Tesis Universitas Pendidikan Indonesia.

[6] Walgito, B. (2010). Pengantar Psikologi Umum. Yogyakarta: Penerbit Andi.

[7] Depdiknas. (2003). Undang-undang RI No.20 Tahun 2003 Tentang Sistem Pendidikan Nasional. Jakarta.

[8] Subana, M. \& Sudrajat (2009). Dasar-Dasar Penelitian Ilmiah Bandung: CV Pustaka Setia.

[9] Sugiyono. (2010). Metode Penelitian Kuantitatif, Kualitatif dan R\&D. Bandung: CV Alfabeta.

[10] Arikunto, S. (2010). Prosedur Penelitian Suatu Pendekatan Praktik. Jakarta: Rineka Cipta.

[11] Gunawan, Y. (2001). Pengantar Bimbingan dan Konseling Buku Panduan Mahasiswa. Jakarta: Prenhallindo.

[12] Winkel, W. S. (2005). Bimbingan dan Konseling di Institus Pendidikan . Jakarta: Gramedia.

[13] Winkel, W. S., \& Hastuti, S. (2006). Bimbingan dan Konseling di Institusi Pendidikan (Edisi Revisi, Cetakan Kelima). Jogjakarta Universitas Sanatha Dharma, Jurusan Ilmu Pendidikan Fakultas Keguruan dan Ilmu Pendidikan. 